\title{
Human Smuggling-Implications on Rights of Migrants: An Examination from the Standpoint of International Law
}

\section{Y. Kathirgamathamby*}

Department of Legal Studies, The Open University of Sri Lanka

\begin{abstract}
Human smuggling is a transnationally planned, coordinated and executed crime that is more often perpetrated by organized criminal networks. It is not merely the smugglers who are in search of the lucrative business but also the smuggled migrants, who give the green light, collaborate and connive in the crime. The impulse to seek new economic opportunities and look for greener pastures, yearning for individual or familial betterment and in certain circumstances, making a getaway from conflict and persecution become the motivating factors for migrants to take the desperate step of consenting to be smuggled out of the country. The modus operandi is by Air, Sea and land where the lives of the smuggled migrants are put at risk during the journey.
\end{abstract}

Lives of the smuggled migrants are put at risk whatever may be the means of transport during the journey. Lacking legal status, migrants are vulnerable to human rights violations, especially of labour rights. They are subject to rigorous controls and even to sexual exploitation. Although migrants may act in collusion with the smugglers, it is increasingly recognized that they are victims of circumstances and stand in dire need of being protected by society.

This article seeks to inquire into and examine the rights of smuggled migrants as are recognized in the context of the provisions in international law. Special attention is given to United Nations Convention against Transnational Organized Crime 2000 (UNCTOC) and the Protocol Against the smuggling of Migrants by Land, Sea

\footnotetext{
${ }^{*}$ Correspondence should be addressed to Y. Kathirgamathamby, Department of Legal Studies, Faculty of Humanities and Social Sciences, The Open University of Sri Lanka (Email: yashokathir@gmail.com)
} 
and Land Supplementing the United National Convention against Transnational Organized Crimes 2000 (Protocol). Besides a careful perusal of these documents, the article also appraises the provisions available under the other International Human Rights Instruments and Conventions relating to status of refugees 1951 .

The first part of the article discusses the right to movement and international laws governing human smuggling. The second part identifies and explains the differences between human trafficking and human smuggling. The third part sheds light on the rights of smuggled migrants available under international law. This part focuses on UNCTOC protocol, CSR and other international human rights instruments (IHR Instruments). The last part of this article is a summary with the inclusion of some suggestions.

Keywords: Human Smuggling, Human Rights, Smuggled Migrants, International Law, Protocol Against the Smuggling of Migrants by Land, Sea and Land

\section{Introduction}

Migratory processes are set in motion by a variety of factors such as landlessness, flight from poverty with no economic prospects in view, natural disasters, internal conflicts and war. Mingled with dreams of freedom from want, the lure of wealth and escape from persecution have been the factors that have impelled people to move away from their homes and familiar surroundings (Migration Report, 2013).

Human migration is a delicate policy issue that has various ramifications having consequences for nearly all countries caught up and involved in the migration process in some way or other. As the process of migration continues unabated and as it involves the relationships of many countries, the need for an integrated and systematized action especially in respect of legislative measures has acquired an ever increasing importance.

Migration can be undertaken through legally accepted channels or it can be done illegally. Illegal movement across borders is being undertaken through trafficking and by smuggling. While the distinction between the two has been explained in detail in the second part of the paper, the main focus of the research is on human smuggling.

Human smuggling is characterized by collusion between the smugglers and those who are smuggled. It is an act of desperation in 
an attempt to escape from poverty, fear of persecution, ethnic strife or civil unrest (Howie, 2013, Jayatilake, 2009). Besides the general factors there may be also country specific factors that set in motion human smuggling. E.g: Emly Howie (2013) in his study found that security threat and loss of confidence in reconciliation, and uncertainty about the future are some of the motivating factors in Sri Lanka. Unemployment is the main reason in China (Cleo, 2000) and in Nigeria (Salt, 2000) Receiving countries are also tempted by cheap availability of labour (Cleo, 1999-2000).

Stringent immigration policy and corrupted officials in the source country are also contributory factors for setting in motion the process of human smuggling. (Kevin Tissre, 2006)

Human smuggling incidents have been increasing throughout the world (World Migration Report 2013, Bali Process 2012). Most countries of origin are from Asia and Africa. Preferred destination countries are Australia, Canada, UK and the US (UNDOC, 2011).

Despite absence of proper data collection, an estimated 40,000 irregular migrants have died worldwide during the risky journey that is an integral part of the human smuggling process from 2000 to 2015 (UNODC, 2015).

The international measures to deal with human smuggling were adopted recently only about two decades ago (UNCTOC, 2000). There are two critical issues that are encountered in addressing human smuggling. They are (1) prevention of human smuggling as a criminal activity (2) Simultaneously protection for victims of human smuggling and ensuring their rights. (Article 2 and 5 of the Protocol)

In addition to UNCTOC and the Protocol, UN model Law against human smuggling and other IHR instruments will also be looked into to see the provisions governing human smuggling.

The first part of the article discusses the Right to movement in conjunction with international laws governing human smuggling. The second part identifies and explains the differences between human trafficking and human smuggling. The third part sheds light on the rights of smuggled migrants available under international law. This part focuses on UNCTOC, Protocol, CSR and other IHR Instruments. This article concludes with is a summary and suggestions. 
In the first part, the author explains the right to movement as a general right. After giving an overview of the right to movement, the author sets out how the right to movement is being governed by immigration policies and procedures of States. Such policies and procedures create constraints to leave of country legally. The author explains human smuggling as one of the illegal modes of travelling to another country. Further, this part gives an overview of the International Legal Framework on human smuggling.

The second part focuses on the misconception of human smuggling and human trafficking being considered as one and the same offence. The author explains the differences between these two modes before discussing the rights of smuggled migrants. The misconception between trafficking and smuggling undermines the development of a separate domestic legal framework in certain countries, and is also an impediment for data collection. Data are scattered and difficult to gather. Moreover, any literature dealing with human smuggling invariably discusses the difference between human trafficking and human smuggling. Recognizing that there are similarities between these two techniques, there is a need for an unambiguous recognition that they are two distinct categories of crimes.

The third part is concerned with the international treaty provisions available to safeguard the rights of smuggled migrants.

The last part summarises the discussion and attempts to make suggestions to strengthen the available international legal framework to achieve the objective of protecting the rights of smuggled migrants.

\section{Statement of the Problem}

Human smuggling has expanded so fast that it has now acquired a global dimension and is posing a serious threat to many countries. There is evidence to show that human smuggling related offences have increased at the same pace as that of the increase in irregular migrants. A large number of victims of human smuggling are vulnerable to human rights abuses before, during, after departure and even after return. It seems that even though several international legal instruments have been adopted, the smuggled migrant's rights are not protected satisfactorily. Therefore, the researcher tries to analyze the provisions of international law governing rights of smuggled migrants to see to what extent the provisions are sufficient to cope with the situation. 


\section{Objectives}

The main objective of this article is to identify and analyze the provisions recognizing rights of smuggled migrants and find any lacunae that may exist in international law and make suggestions to remedy them. The secondary objective of the paper is to enhance and reinforce knowledge on the rights of smuggled migrants under the provisions that are available in international human rights law.

\section{Methodology}

This is both a descriptive and an analytical study. The author describes the provisions available under international law and analyzes them. The justification for adopting this methodology is to achieve the main objective of the research paper of understanding as to what degree measures are available in international law and identify lacunae that may exist.

UNCTOC, Protocol, International Covenant on Civil and Political Rights (ICCPR) International Covenant on Economic, Social and Cultural rights, (ICESCR) Convention on the Rights of the Child, (CRC) Convention against Torture (CAT) have been used as primary data, and Journal articles, reports, guide books, web resources have been analyzed as secondary data.

\section{Theoretical Framework}

Global literature available on human smuggling brings the issue of human smuggling under different theoretical models (Theodre, 2013). Human Rights based Model is one of the theoretical approaches developed by scholars. Research studies based on Human rights based model analysis is about the role of the international, regional, and national actors criminalizing smuggling and protecting the rights of the smuggled migrants. According to Obakaoto (2005) this model theorizes that the states have obligations to ensure the rights of smuggled migrants irrespective of their status. Most of the literature is based on this focus on the obligations of the destination countries. According to UNCTOC and the Protocol, protecting rights of smuggled migrants are transnational duties. Andreas Schloenhardt, and Kate L Stacey suggests that any action with regard to human smugglers should take into consideration the human rights approach. 
International law requires States to take legal, institutional and other measures to ensure rights of smuggled migrants. In the first instance, the Country of origin has a responsibility to address the root causes of human smuggling. The countries of destination as well as the transit countries also bear a responsibility to safeguard human rights

In the context of the human rights based model, the author looks as to what extent international law has incorporated provisions to protect the rights of smuggled migrants.

\section{Results and Discussion}

\section{Part I -1.1 Right to Movement as a Human Right}

One of the primary concerns of the United Nations Organization established at the end of World War II was to give priority to the rights of migratory settlers, as the war itself had generated displacements and migration on a massive scale. Universal Declaration of Human Rights (UDHR 1948) was the first document in which human rights were codified after the Second World War. Article 13 of the UDHR recognizes the right to movement and asylum. Even before adopting major binding international human rights instruments such as ICCPR and ICESCR in 1966, the CSR was adopted in 1951 to provide asylum based on five grounds enumerated under Article 2 (1) A of the convention. It was initially limited to protecting European refugees of Second World War from before 1 January 1951. Later, this Convention was supplemented by 1967 protocol to remove the time limit and cover all territories in the world (Paul Weis, 2001-2016). It is clear from the above measures that UN had given prior importance to rights of migrants.

Whether migrants or not, the UN deliberated on the essential rights that should be available to all human beings and after detailed discussions by representatives of all countries, the decisions were enshrined in what came to be known as the UDHR. Various international instruments of the UN were promulgated subsequent to this declaration. Since 1945, there have been several UN conventions declarations and protocols that have directly and indirectly dealt with issues concerning the rights of migrants.

Article 13 of the UDHR states "Everyone has the right to freedom of movement and residence within the borders of each State. Everyone has the right to leave any country, including his own, and return to his country. Similar provisions could be found in other IHR instruments 
(ICCPR (Article 12), Convention on the Elimination of All forms of Racial Discrimination, (Article 5). The framework Convention for the Protection of National Minorities of Council of Europe has expressed provisions to recognize the right to movement.

In exercising this right, people have adopted different modus operandi to move from the country of origin to another both that come within the framework of legality and also through unlawful practices.

The international human rights law requires the states to protect the rights of everyone irrespective of their status. Nevertheless, it has to be observed that countries have discretion to regulate their migration policy. However, Human Rights Committee in its general comments 27 (CCPR/C/21/Rev.1/Add.9 (1999) states that the restrictions on the rights to movement should be provided by law. The committee emphasizes in the same comment that "The restrictive measures must not "swallow the rule". "The application of restrictions in any individual case must be based on clear legal grounds and meet the test of necessity and the requirements of proportionality".

Countries have put in place immigration laws and administrative guidelines to govern legal migration. Anyone wanting to migrate for legitimate reasons has to fulfill statutory and administrative requirements of host countries. Applicant has to satisfy the requirements of host countries. This may be perceived as insurmountable obstacles. Given such a situation, it is no surprise that many people wish to choose the services of the smugglers though expensive. Smugglers take the responsibility of organizing documents and passage to destinations.

If someone wishes to seek refugee status due to persecution as enumerated under the CSR 1951, he or she has to satisfy the requirements established under that convention. Article 2 (1(A) of the refugee CSR defines who is a refugee. The refugee status can be claimed based on ground of ethnicity, nationality, religion, political opinion and particular social group. Policies and laws have been developed to regulate all types' migration and refugee claims. Canada's Immigration and Refugee Protection Act 2001, Australian Migration Act 1958 with amendments and US Refugee Act of 1980 are some of the laws which grant visa or refugee status on conventional grounds. If they fail to prove the conditions laid down under these laws they will be sent back home. 


\subsection{International Law Governing Human Smuggling}

According to Salt \& stain (1997) the discussion on organized transnational crimes, trafficking and human smuggling has commenced in the 1990s. Increasing incidents of human smuggling has led the international community to take legal measures in prevention of human smuggling as an organized crime and protect the rights of smuggled migrants. An International legal framework has been developed to regulate the issue of human smuggling.

Italy and Austria played a pioneering role in the adoption of the UNCTOC. The main objective of the UNCTOC was to take measures against transnational organized crimes. International cooperation, creation of domestic legislations the adoption of extradition laws, mutual legal assistance and law enforcement cooperation are the measures critical for achieving the main objective. It is after the UNCTOC that two different protocols were adopted to address human trafficking and human smuggling.

Article 4 of the Protocol applies when the smuggling of migrants involves an organized group. The term organized criminal group is defined under article 2(a) of the UNCTOC as "Organized criminal group" shall mean a structured group of three or more persons, existing for a period of time and acting in concert with the aim of committing one or more serious crimes or offences established in accordance with this Convention, in order to obtain, directly or indirectly, a financial or other material benefit".

Article 3(a) of the Protocol has defined the smuggling of migrants as 'the procurement, in order to obtain, directly or indirectly, a financial or other material benefit, of the illegal entry of a person into a State Party of which the person is not a national or a permanent resident"

In order to qualify a smuggling offence the above articles should be read together. To be characterized as human smuggling at least there must be an involvement of three persons.

Financial benefit is the core element to prove the crime. Some states have adopted domestic laws in line with Article 39a) of the protocol. E.g: BO10 v Canada (Citizenship and Immigration), (2015 SCC 58) the Supreme Court has concluded that sec. $37(1)(b)$ of the Immigration and Refugee Protection Act applies only to people who act to further illegal entry of asylum-seekers in order to obtain, directly or indirectly, a financial or other material benefit in the context of transnational organized crime. The acts of humanitarian 
and mutual aid (including aid between family members) do not constitute people smuggling under the Act.

Both UNCTO and the protocol require States parties to take appropriate legal and other measures. The protocol defines human smuggling (Article 3 (a) and urges States to enact laws to punish human smugglers and protect the irregular migrant. A model law has been prepared by UN taking into consideration the various worldwide domestic laws in incorporating punitive provisions for smugglers. The model law also covers awareness creation about risks, international cooperation on resource sharing, exchange of information, rights to assistance, and protection for smuggled migrants.

\section{Part II -Human Trafficking and Human Smuggling}

Trafficking and smuggling are becoming big business and increasingly criminality is being integrated into this business. Both countries of origin, and destination countries are afflicted and these seriously impact on their international relations, security and economy. There is however, a marked difference between trafficking and smuggling.

Both trafficking and smuggling, are systems which facilitate movement from home country to destination countries in search of improved incomes and a better way of life.

Trafficking can take place within the country whereas smuggling needs to have crossing of borders. Trafficking victims do not violate law intentionally but smuggled migrants do so as they themselves collude in the process.

Trafficking draws apprehension and anxiety not only because of the manner in which a person enters into a country but also about his/her working conditions and whether he/she consented to the irregular entry and the working conditions (ILO, 2011) Trafficking is prompted by a sense of desperation and marked by severe forms of labor exploitation and also commercialized sexual abuse. (UNCTOC, 2000)

Smuggling is to facilitate and promote the illegal crossing of a country's border stealthily. Smugglers will therefore often be present and participate actively during the recruitment and transport processes. According to Salt (2000) trafficking involves a long-term 
relationship between the trafficker and the trafficked person. It usually involves the trafficker, or associates, subjecting the trafficked person(s) to exploitative labour environments through removal of identity documents, withholding of payment, abuse and ill-treatment, and the continual threat of exposure to authorities and deportation.

Smuggling is clearly concerned with the manner in which a person enters into a country and with the involvement of third parties who assist him or her to active entry. A migrant enters into a contract with a smuggler to pay a fee to the smuggler. Often during smuggling process human rights become a casualty.

According to Theodore (Bilger as cited in Theodore Baird, 2013) there are some authors who argue that smuggled migrants cannot be reckoned as victims but should rather be considered and looked upon as clients because they seek a service from the smugglers through providing them with remuneration. In this context destination countries can look upon the smuggled migrants not as victims but as wrongdoers whereas trafficked migrants will be viewed as human rights victims. However the contention of Jandi, (2007) that "quite often the smuggled migrants during the process of smuggling are applied the same criteria as are applied to trafficked victims thereby undergoing the same trauma is worthy of note". The line between smuggled and trafficked migrants is rather blurred and changes also occur during operation.

Authors have expressed the view that there are considerable difficulties in making out difference between smuggling and trafficking (Louis Shelly, 2014). There are times when people who were smuggled after paying a considerable amount of money undergo sexual and labour exploitation and are accorded the same treatment as are given to trafficking victims (UNODC, 2006). The argument advanced that smuggled illegal migrants are often exposed to similar cases of danger or discomfort during the long journeys as trafficked victims has to be noted.

Notwithstanding the pitfalls and hazards occurring often under degrading conditions, there has been an increase in the number of persons who with their own consent are being facilitated to enter into countries using this illegal mode.

Those who organize trafficking do not insist on fee or an advance payment from victim. They collect fees from the well-connected business network. Victims are often told that they need not to make 
any form of advance payment in order to be taken out of the country. There is some kind of pre- arrangement where these people are to be employed. The characteristic feature of human smuggling is not only collusion but also payment of fee to the smugglers to smuggle them out of the country. The victims are often dropped in the border of the destination country.

Because of the confusion between the different modes adopted for these two processes, obtaining information even from official sources is an encounter with a multitude of difficulties.

Studies have been carried out on these two distinct modes adopted by those who engage in the operation. Recognizing this already, laws have been developed in certain countries. However, awareness about this issue is inadequate and makes it rather difficult both to punish the smuggler as well as protect the victims.

\section{Part III -Rights of Smuggled Migrants under International Legal Framework}

International human rights law recognizes that all persons should be recognized as person before law are to be treated as equal before law and entitled for equal protection of law. Smuggled migrants are no exception. Joseph H Caren (2005) states that "people ought to possess simply by virtue of being within in the jurisdiction of the state whether they have permission to be there or not and whether they are obeying the laws or not". He points out while agreeing generally that the rights of irregular migrants should be protected, he specifically points out that right to security of one's person, right to food, medical care freedom, freedom of religion and freedom of speech and fair trial that are important rights of the irregular migrants. Smuggled migrants are also entitled to basic human rights regardless of their status. Their rights should be protected at all stages by those who intercept, identify and detain.

There is a vulnerability of irregular migrants to human rights abuses, discrimination, marginalization and exclusion. These are further accentuated by exploitation, and mistreatment by employers and also by official authorities. Smuggled migrants are also subject to sexual exploitation (Erick Gjerdingen 2009).

The woe of an irregular migrant begins from the time of departure up to their arrival at their destination and continues further. These 
begin before departure, during transit at the border, within the country of destination and even after return to the country of origin.

During their journey, migrants often take great risks to circumvent official frontier or police controls, and some meet with death en route, sometimes under grim and appalling circumstances.

Smuggling is fought with many dangers. Sometimes they are captured by criminal gangs, (Andreas Schloenhardt and Kate L Stacey, 2013) There are many instances of being denied adequate food and also an absence of health care (ibid.,). Sometimes they are packed in ill ventilated containers and are subject to risk of being suffocated to death. As the vessels are not of accepted quality, there are instances of the entire vessels along with its crew and passengers being sunk in the sea.

Those who successfully enter into countries work under poor conditions. Cleo points (1999-2000) out those smuggled migrants are paid low wages. As those who volunteer themselves to be smuggled lack in legal status, they are put into a predicament of being not able to seek basic economic, social and cultural rights. Bethany Hastie (2009) contends that criminal based model has failed and therefore, human rights based model should be adopted in addressing this issue. Smuggled migrants undergo harassment at the work place and are also subject to sexual exploitation. Lack of legal status, results in a denial of most of the basic economic, social and cultural rights.

Some countries impose mandatory detention after apprehension. Andrew Trotte and Malt Garozo (2012) claims that the mandatory policy introduced by Australia to address human smuggling denies migrants rights and amounts to violation of international obligations undertaken through various international human rights instruments.

States are required to take measures in line with international obligations and responsibilities under international conventions relating to human rights, humanitarian law, and refugee law.

Article 3 (a), of the protocol defines smuggling as mentioned above. Article 3, (b), of the Protocol defines "illegal entry" The above two provisions refer to illegal entry into a country. When a migrant enters into another by violating the immigration law, he becomes an irregular migrant. Considering the vulnerable situation of smuggled 
migrants, legal provisions have been incorporated into the protocol to provide minimum protection to the victims.

In relation to the human smuggling issue, both UNCTOC and the Protocol should be taken together. However, it is to be noted that some countries become party to the UNCTOC but do not ratify the protocol. States however are required to protect the rights of everyone under International human rights and customary international law. If a state does not ratify or accede to the protocol, then it is not possible to deal with human smuggling as it is the Protocol specially enacted for the purpose. E.g: Sri Lanka has ratified UNCTOC but is not a party to the protocol. Therefore, it can be said that Sri Lanka is not obliged under protocol to eradicate Human smuggling and protect the rights of smuggled migrants. However, it may be argued that SL is party to other major IHR instruments. However, it is only by ratifying the protocol that there will be a definite and clear recognition of the issues that arise out of human smuggling.

Article 6 of the protocol requires states to criminalize smuggling of migrants and to afford protection to the victims. Article 16 should be read together with article 6. Article 16 states as follows :"in implementing this Protocol, each State party shall take, consistent with its obligations under international law, all appropriate measures, including legislation if necessary, to preserve and protect the rights of persons who have been the object of conduct set forth in article 6 of this Protocol as accorded under applicable international law, in particular the right to life and the right not to be subjected to torture or other cruel, inhuman or degrading treatment or punishment."

Article 9 requires states to safeguard the people on board. Article 16 of the Protocol urges the state parties to 'afford appropriate assistance' to smuggled migrants. It also includes legislative and other measures too. States should protect migrants from physical violence. Further, article 6 emphasizes that smuggled migrants should be protected in accordance with relevant international treaties. State parties to the protocol have to ensure that smuggled migrants have access to consular services when they are detained.

According to Schenhardt \& Stacy (2014) "Article 16 does not confer any rights upon smuggled migrants nor does it create new obligations on state parties, beyond those already recognized in international humanitarian law". This article does not give any specific guidelines as to the protection and violence against irregular migrants. There is 
no explicit requirement that host country provides safe accommodation, or other types of protection. Article 16(3), 'affords appropriate assistance' to migrants whose lives or safety are endangered by reason of having migrated. Article 16(4), recognizes the particular vulnerability of women and children.

Article 16(5) also implies an obligation on state parties to facilitate communication between smuggled migrants and relevant consulate in situations where the migrants entered the host country illegally. Although article 16 gives directions to host countries, it also gives discretion. Therefore, states can ignore these obligations.

Erick Gjerdingen (2009) points out that that smuggling protocol aims to impose criminal sanctions for smugglers not intending to protect human rights of the smuggled migrants as with the human trafficking victims. Obakato, (2005) remarks that "the protocol fails to recognize the human rights aspects of migrant smuggling and that it shows little regard for 'political, social and economic solutions' to the problem." Erick Gjerdingen (2006) critically argues that the smuggling protocol mainly focuses on the punishing of the offenders, rather than protecting the smuggled migrants as compared with trafficking protocol.

The CSR and smuggling Protocol relating to the Status of Refugees should be read together. The principle of non-refoulement has been incorporated into Article 19 of the Smuggling Protocol. According to CSR, irregular migrants are not expelled from the country if their life is under threat. For example, illegal entry does not affect the right to seek asylum (BALI PROCESS, 2012).

The Model Law against the smuggling of migrants was developed by the UN to protect and to address the issue of human smuggling. UNCTOC has also included a number of provisions requiring state parties to take measures to assist and to protect smuggled migrants and witness (Article 25 of the UNCTOC). UNTOC emphasizes that regardless of their immigration status, smuggled migrants have the right to expect that their human rights and dignity should be upheld. Customary international law prevents states from punishing refugees merely entering into countries.

The gaps in UNCTOC and Protocol have been sought to be filled through other IHR. The IHR instruments have general and specific provisions with regard to the migrant's rights, irrespective of their status as to whether they are regular or irregular. Since there are shortfalls in the protocol, other human rights instruments have been 
employed to fill the shortfalls for the protection of smuggled migrants.

Although not binding, article 3, paragraph 1, of the 1967 Declaration on Territorial Asylum and article 14 of the UDHR provide that every person has a right to seek and enjoy in other countries asylum from persecution.

Article 2 of the ICCPR and ICESCR urge the state parties to protect the rights of everyone, including irregular migrants without any manner of discrimination. This particular aspect was considered and has been clearly set out by the Human Rights Committee in its general comment 15 . Other human rights instruments also ensure nondiscrimination in ensuring rights to non-citizens.

Article 1 of the CERD, Article 3 of the CEDAW, Article 7 of the International Convention on the Protection of the Rights of All Migrant Workers and Members of Their Families ensure the principle of non- discrimination with regard to non- citizens which includes smuggled migrants irrespective of their legal status. Article 2, paragraph 1, of CRC ensures that the child is protected against all forms of discrimination or punishment of the child irrespective of the status of the parents.

According to General comment 31 on Human rights committee, Article 7 of the ICCPR and Convention against torture (CAT) Article 3 , specifically requires that "States parties must not expose individuals to the danger of torture or cruel, inhuman or degrading treatment or punishment upon return to another country by way of their extradition, expulsion or refoulement." Similar provision is available under the CSR (Article 33).

Everyone is free from arbitrary arrest and detention (Article 9, ICCPR). Conditions of detention must comply with basic minimum human rights standards. There must be regular independent monitoring of places of detention to ensure that those standards are met. States should ratify the Optional Protocol to the CAT as this provides a strong legal basis for a regular and independent monitoring of places of detention.

Regardless of status of migrants, they are entitled to economic rights such as housing, health, food, education and sanitation. Article 12 of ICESCR ensures right to health of everyone. General Comment No. 14 (2000) (E/C.12/2000/4) the Committee stated that: "States 
are under the obligation to respect the right to health, by inter alia, refraining from denying or limiting equal access for all persons, including prisoners or detainees, minorities, asylum-seekers and illegal immigrants, to preventative, curative and palliative health services; abstaining from enforcing discriminatory practices as a State policy".

Article 19, paragraph 2, of the protocol seeks to ensure that domestic laws pertaining to smuggling of migrants are not designed or applied in a manner that discriminates against smuggled migrants or irregular residents by reason of their status as such.

Scholars (Obakato, 2005) argue that the obligations in the Protocol are stronger than those in human rights treaties, and therefore, relying on the human rights framework undercuts the transnational obligations under the Protocol.

However, it is to be noted that some provisions in the Protocol are drawn from Human rights conventions. E.g: Obakato, points out that the model law developed by the UN draws certain provisions of the ICCPR. Example, the Model law states that the smuggled migrants are entitled to urgent medical care. This particular provision is drawn from the ICCPR.

A Combined reading of Article 16 of the Protocol and Article 28 of the CRC seems to show that the smuggled children are entitled to an education. The human rights treaty bodies have accepted the view that a violation of immigration laws does not deprive migrants of the fundamental human rights provided by human rights instruments nor does it affect the obligation of states to protect migrants in an irregular situation (UNODC, 2010).

Article 2 and 19 of the protocol drive to preserve the rights of smuggled migrants. Article 19 draws particular attention to the CSR. Article 33 of the CSR urges States not to return the people if they will undergo torture in the country of origin. This provision is similar to Article 7 of the ICCPR and Article 3 of the CAT.

Aljahani (2015) points out that, "....although these mechanisms have been adopted to regulate the transnational organized crime, there are gaps and loopholes in these instruments". Some literature suggests that major amendments are required for UNCTOC and protocol in terms of the definition of the crime, state parties' obligations and rights of irregular migrants. 
In order to fulfill the said obligation under UNCTOC, Protocol and other IHR instruments, several measures are being taken by the States. Eg bilateral agreements are signed between countries to penalize the offence of human smuggling and protect the rights of smuggled migrants. (Eg: MOU between the Government of Australia and the government of Sri Lanka 2012). Resource and information sharing, and mutual legal assistance which are in place needs scrutiny. Some states have made legal and administrative arrangements Eg. Sri Lanka Mutual legal Assistance Act 2002 facilitates the investigations and trials in transnational crimes. However, closer examination has shown the limitations and constraints in these mechanisms.

Articles 16 of the protocol urges that where existing national law of state party does not conform to the protocol, amendments should be brought to preserve and protect the basic rights of smuggled migrants and illegal residents to protect against violence.

\section{Part IV- Conclusion}

Human smuggling incorporates and involves several countries such as the country of origin, of transit and destination. It, therefore, has an impact on the international relations, security and economy of all these countries. There would be migrants who make large payments to the smugglers and become enmeshed in the hazardous operation which sometimes pursues them even after they return to the country of origin. However, one is taken by surprise that despite the perils and pitfalls, there have indeed been cases of smuggled persons who after having been deported back make an attempt to be smuggled out once again. It is indicative of desperation and calls for a sympathetic understanding and humanitarian approach for the migrants.

International law on human smuggling has evolved since 1990s. Prior to this development, international human rights law had a role in addressing the issues of smuggled migrants. This study shows that the UNCTOC and the smuggling Protocol have provisions in regard to protecting rights of smuggled migrants. Even after development of these special international instruments, there are several gaps and loopholes which need urgent attention

The important lacuna is that these provisions are only directory in nature. One such example is that the protocol requires the states to take action to ensure rights of smuggled migrants but does not give 
any mandatory directives to states. Thus, States can use discretionary power and disregard the protocol's objectives

The study clearly shows that the smuggling protocol focuses more on punishing the offenders rather than protection of rights of smuggled migrants.

Even States that have not ratified the UNCTOC and the smuggling protocol have obligations under other international human rights instruments. The recommendation is made that instead of depending on other human rights conventions, the protocol itself must enshrine the specific rights of migrants. They must be required to take legislative and non - legislative measures in order to ensure rights of smuggled migrants.

It must also be noted that these are countries which have not ratified relevant human rights conventions and therefore, these conventions cannot be invoked for protection of migrants.

Although UNCTOC may be ratified, this alone is insufficient to ensure rights of the migrants. It is necessary to ratify the protocol to provide meaningful protection.

Human smuggling is fraught with many dangers. There is uncertainty about the reception in the countries where the migrants enter. Countries involved in the process are put into great inconvenience and difficulties. While it is true that the countries of origin have to take meaningful steps to eradicate the root causes of smuggling one has to recognize the global dimension of this problem. The responsibility cannot be left only with the countries of origin only but also the countries of intended migration. Cooperation is required to handle this problem. Already some steps are being taken. But this has to be strengthened much more.

There is serious lacuna in that there is no treaty body that is charged with monitoring. Regular reporting by States and a watch dog function by a treaty body are urgently in need.

There is a Protocol provision which says that the States should not target the smuggled migrants as offenders. However, other provisions note that States have discretion to enact laws to punish them. This provision undermines the rights of smuggled migrants.

As a multiplicity of problems are caused by human smuggling, exchange of information and coordinated responses among the 
affected countries have become indispensable and unavoidable. Coordination becomes all the more necessary as untold problems and hardships are caused to the migrants who are being subjected to human rights abuses, discrimination, marginalization and exclusion with problems persisting even after return to the country of origin. Although UNCTOC and the smuggling protocol aims to protect rights of smuggled migrants, the study shows that the convention does not impose any legal obligation. The terms are vague and the countries are allowed to take action as they wish.

\section{References}

\section{Books}

Galina Cornelisse, (2010). Immigration Detention and Human Rights Rethinking Territorial Sovereignty: Freedom of Movement: The Right to Leave as a Human Right,Martinis NIJHOFF Publishers p 135-273).

Satvinder S. Juss, (2007). International Migration and

Global Justice, Ashgate Publishing Company p, 65-101.

\section{Articles}

Abdelnaser A, (2015). the Legal Definition of the Smuggling of Migrants in Light of the Provisions of the Migrant Smuggling Protocol, Journal of Criminal Law, June 9 (2015).

Andreas Schloenhardt, Kate L Stacey, (2013). Assistance and

Protection of Smuggled Migrants: International Law and Australian Practice Sydney Law Review 35(53) p 53-84 (2013).

Andrew Trotter and Matt Garozza (2012). Mandatory Sentence of

People Smuggling Melbourne University Law Review [36 (552).

Bethany Hastie, (2014). Criminalizing Irregular Migration: The Failure of the Deterrence Model and the Need for a Human Rights-Based Framework, IANL 28, 213-236.

Cleo J. Kung, (1999-2000). Supporting the Snakeheads: Human Smuggling from China and the 1996 Amendment to the U.S. Statutory Definition of Refugee, J. Crim. L. \& Criminology 90(4), p 1271. 
Erick Gjerdingen (2009). Suffocation inside a cold storage truck and other problems with trafficking as "exploitation" and smuggling as "choice" along the Thai-Burmese Border, 26 Ariz. J. Int'l \& Comp. Law, p, 699.

H. E. Sheikha Haya Rashed Al Khalifa, (Winter 2006). Chairperson's \Summary of the United Nations General Assembly HighLevel Dialogue on International Migration and Development, The International Migration Review, 40, (4) pp. 966-972.

Johan Salt (2000). Trafficking and Human Smuggling: A European Perspective, Blackwell publishers Ltd, 31- 56.

Joseph H. Carens (2008). The Rights of Irregular Migrants Ethics and International Affairs $22(2): 163-186$.

Michael Jandi (2007). Irregular Migration, Human Smuggling, and the Eastern Enlargement of the European Union, (Summer, 2007). The International Migration Review, Vol. 41, No. 2, pp. 291-315.

Obakato Tom (2005). Smuggling of Human Beings from a Human Rights Perspective: Obligations of Non-State and State Actors under International Human Rights Law, Int $\mathrm{J}$ Refugee Law 17 (2):394-415.

\section{Internet Resources}

Ollus, Natalia, Protocol against the smuggling of migrants by land, air and sea, supplementing The United Nations Convention against Transnational Organized Crime: a tool for criminal Justice personnel Paper presented at the 122nd international training course available at www.unafei.or.jp.english/pdf.RS_No62/No62_07VE_ollus2.pd f last visited on 20.11.2015.

Loius Shelly (2014). Human smuggling and Trafficking into Europe A Comparative Perspective Translantic Council on Migration, Migration Policy institute available at file:/ / C:/Users/yaso/Downloads/BadActorsShelleyFINALWEB\%20(1).pdf last visited 10.01.2016.

Helsinki,(2000). European Institute for Crime Prevention and Control, affiliated with the United Nations, available at www.oas.org/juridico/MLA/en/Treaties/en_Prot_Smug_Migr_ Land_Air_accessed on last visited on 20.11.2015. 
Paul Weis The Travaux Preparations Analyzed with a Commentary available at www.unhcr.org/protection/travaux/4ca34be29/refugeeconvention-195 1-travaux-preparatoires-analysedcommentary-dr-paul.html last visited on 15.05.2016.

Theodore Baird, Theoretical Approaches to Human Smuggling DIIS working Paper, (2013). Vesterkopi A S available at https://www.econstor.eu/dspace/bitstream/10419/122263/ 1/771271093.pdf last visited 11.11.2015.

International Framework for Action implementing the smuggling of Migrants Protocol (2011) UNODC, available at https://www.unodc.org/documents/humantrafficking/Migrant Smuggling/Framework_for_Action_Smuggling_of_Migrants.pdf last visited 10.03.2016.

Yury Fedotov, (2012). The fate of smuggled migrants: Confronting violence and exploitation available at http://www.unodc.org/unodc/en/frontpage/ 2012/November/the-fate-of-smuggled-migrants-confrontingviolence-and-exploitation.html last visited 20.05.2016.

\section{Reports \& Guide Book}

Corruption and the Smuggling of Migrants - Issue Paper United Nations Vienna 2013

Migration and International Human Rights Law - A Practitioners' guide updated version 2014, - (International Commission of Jurists) UN Migration Report 2013

\section{Conventions, Declarations and Protocols}

Convention against Torture 1984

Convention on the Rights of the Child 1989

Convention relating to Status of Refugees 1951

International Covenant on Civil and Political Rights 1966

International Covenant on Economic, Social and Cultural Rights Universal Declaration on Human Rights

United Nations Convention against Transnational Organized Crime 200 
The Protocol against the Smuggling of Migrants by Land, Sea and Air, supplementing the Convention against Transnational Organized Crime 2000.

Received: 30-3-2016 Revised: 30-06-2016 Accepted: 03-07-2016 